\title{
Paideusis
}

\section{Reconsidering Socrates' Influence on Moral Education Through the Elenchus}

\section{Claude Gendron}

Volume 12, Number 2, 1999

URI: https://id.erudit.org/iderudit/1073087ar

DOI: https://doi.org/10.7202/1073087ar

See table of contents

Publisher(s)

Canadian Philosophy of Education Society

ISSN

0838-4517 (print)

1916-0348 (digital)

Explore this journal

Cite this article

Gendron, C. (1999). Reconsidering Socrates' Influence on Moral Education

Through the Elenchus. Paideusis, 12(2), 19-31. https://doi.org/10.7202/1073087ar

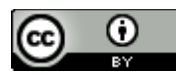

This document is protected by copyright law. Use of the services of Erudit (including reproduction) is subject to its terms and conditions, which can be viewed online.

https://apropos.erudit.org/en/users/policy-on-use/
This article is disseminated and preserved by Érudit.

Érudit is a non-profit inter-university consortium of the Université de Montréal, Université Laval, and the Université du Québec à Montréal. Its mission is to promote and disseminate research.

https://www.erudit.org/en/ 


\title{
Reconsidering Socrates' Influence on Moral Education through the Elenchus
}

\author{
Claude Gendron, Faculté des Sciences de l'Education, Université Laval
}

Looking at contemporary works in moral education, one can see that Socrates' shadow still hangs over theoreticians writing in the field. ${ }^{1}$ Thus, Lawrence Kohlberg (cognitive-developmental approach), John Wilson (analytical approach), and Matthew Lipman (philosophy for children approach) all consider the Socratic art of practising dialogue as a discursive moral education model. ${ }^{2}$ However, other researchers who attribute a major role to dialogue in education have recently shown some reserve towards this discussion model. ${ }^{3}$ The purpose of this paper is to develop a critical reflection on this model by examining, specifically, the elenchus method from an ethics perspective. ${ }^{4}$

Why look at Socrates' practice of dialogue through the elenchus? First, the elenchus seems to correspond to what is most often referred to when educators speak of the Socratic method or Socratic teaching. ${ }^{5}$ Secondly, the elenchus seems to constitute the foundation of the type of Platonic dialogue of most interest to Kohlberg (who remains one of the theoreticians who has had the greatest influence on the domain of contemporary moral education). Kohlberg states that his most relevant source is not Freud, Skinner, or Piaget, but Socrates. ${ }^{6}$ More specifically, he lets us know that his conception of the teaching of virtue involves many elements associated with a Socratic perspective rather than a Platonic one because it draws on a view of moral education expressed in Plato's first dialogues (that is, the "Socratic dialogues"7). Socrates constantly resorts to the elenchus method in these dialogues. ${ }^{8}$

General Description of the Elenchus Method, ${ }^{9}$ or Elegkhos, ${ }^{10}$ or Exetasis and Basanismus, 11

Curiously, Plato does not define this method which is used so consistently by Socrates. Indeed, as emphasized by Gregory Vlastos, the elenchus was never itself the object of Socrates' questioning. ${ }^{12}$ Interpretation of this method's characteristics must, therefore, be based on analysis of its practice and on some descriptions given by Plato.

Richard Robinson presents two definitions (in the larger sense and in the narrower sense) of the elenchus. According to him, the elenchus represents, in the larger sense, a questioning of the truth-value of a statement made by a person. However, it is often the case that ". . . the truth-value expected is falsehood. ... Elenchus in the narrower sense is a form of cross-examination or refutation." 13 The elenchus as refutation is described in the following way:

[Socrates] is always putting to somebody some general question, usually in the field of ethics. Having received an answer (let us call it the primary answer), he asks many more questions. These secondary questions differ from the primary one in that, whereas that [sic] was a matter of real doubt and difficulty, the answers to all these seem obvious and inescapable. Socrates usually phrases them so that the natural answer is yes; and if you say anything else you are likely to seem irrational or at least queer. . . [At the end of the elenchus], propositions to which the answerer feels he must agree have entailed the falsehood of his original assertion. ${ }^{14}$ 
In the Sophist, the elenchus is compared to a purgative cure administered to heal the pretensions to knowledge. ${ }^{15}$ As the analogy suggests, the therapeutic action of this medicine does not take place smoothly. It consists in a destabilization of the knowledge taken for granted; this necessarily causes pain but the benefit will be recognized later on. ${ }^{16}$ Based on the use of questions and answers, the elenchus constitutes an instrument that challenges the beliefs held by Socrates' interlocutors. Just as this purgation of false beliefs is considered to occasion a sense of liberation, it is also considered to be cathartic. ${ }^{17}$ Most often, the elenchus allows the philosopher to "diagnose" ethical beliefs. For example, Socrates' questioning is aimed at courage in the Laches, at piety in the Eutyphro, and at friendship in the Lysis.

Socrates' tendency to upset the equilibrium of his interlocutor's beliefs when using his method has led to various interpretations of his ultimate goals. It has been asked whether the elenchus constituted an intellectual trap intended to break down the theses of his adversaries. For instance, Vlastos writes: "His tactics seem unfriendly from the start. Instead of trying to pilot you around the rocks, he picks one under water a long way ahead where you would never suspect it and then makes sure you get all the wind you need to run full-sail into it and smash your keel upon it." 18 The ethical foundations of the elenchus are, therefore, open to doubt. In the following sections, I propose a reflection on these foundations. My purpose is to ask the following questions: Can we consider Socratic questioning to be open? Can we presume, as did Plato, that the elenchus will have a therapeutic effect on moral development? What type of rationality is valued by the Platonic elenchus? And, finally, what conception of caring for others emerges from the dialogues?

\section{Socratic Questioning: Open or Closed?}

One of the most controversial themes concerning the character of Socrates is the credibility of his ignorance. On the one hand, it is well-known that Socrates claims only to know that he is certain of his ignorance; on the other hand, he gives the impression of a chess player who can anticipate, in an extremely precise way, how the game will unfold. The issue of Socrates' ignorance is very important because it concerns the value attributed to the openness of discussion-that is, the absence of predetermined conclusions. Is Socrates really ignorant, as he so often pretends to be, or is he feigning ignorance, knowing full well the direction the dialogue will take? Vlastos interprets this claim of ignorance as an affirmation of Socrates' willingness to submit his own beliefs to doubt. If it is true that, at the dialogue's beginning, Socrates already anticipates some of the conclusions of the topics being discussed, he remains, in Vlastos' view, ready to modify those conclusions if better intuitions are put forward to solve the problem, or if he is persuaded that his arguments are incorrect. ${ }^{19}$ Therefore, Socrates seems to be a sort of hardened researcher able to pinpoint the mistakes his co-researchers are about to make but also prepared to question his own theoretical framework.

Certain elements support this hypothesis that the dialogues are the expression of joint research: for example, we can consider that the absence of conclusions in dialogues such as the Protagoras or the Theaetetus is a manifestation of a certain openness to exploration, despite the presence of refutations directed by Socrates. Following the logic of what has been previously argued, it is indeed 
possible to maintain that in these dialogues, Socrates is obviously skilled at pinpointing his interlocutors' errors in reasoning but that he, nonetheless, does not have any "answer" to the problem at hand.

It is difficult, however, to give similar credit to Socratic ignorance when it comes to the famous discussion of the Meno between Socrates and the slave, owing to the obvious knowledge Socrates had about the conclusions of this elenchus which appears to be closer to a lesson than joint research. ${ }^{20}$ In such a case, does the teleological character of the elenchus represent an obstacle to dialogue? It all depends on the way this notion is defined. For example, Burbules favours a "generic view of dialogue" 21 that leads him to identify four types of dialogues (conversation, instruction, debate, and inquiry). He considers the dialogue between Socrates and the slave as one of instruction (instruction presupposes the presence of predetermined conclusions) useful for the learning of cognitive processes: ". . . what this Socratic legacy has given us is the insight that one valuable process of teaching through dialogue can be a giveand-take that is playful and directed by one of the parties in order to assist and guide the other through the steps of complex and developmentally novel cognitive process.",22 In the domain of education, the elenchus from the Meno takes on particular importance because the questioning directed toward the slave is very often considered as the best illustration of the "Socratic method.",23

On examining the Socrates/slave relationship, one first notices that the slave is for Socrates an instrument whose purpose is to prove to Meno that learning is remembering. The Other (i.e., the slave) is, thus, understood as being a means to an end and corresponds, in the language of the philosopher Martin Buber, to "It" rather than "Thou."

As the discussion comes to a close, the slave makes a "discovery" about a specific point that Socrates had chosen. In fact, Socrates has been endeavoring to retrieve precise geometric data from the amnesia of the slave's soul. This incessant pursuit of a "forgotten" truth guides everything that Socrates says during the discussion. The slave is constantly nudged toward the end point foreseen by Socrates and his contribution to the dialogue is meticulously kept in line by the authority figure whom the philosopher incarnates.

In moral education, such conditions for discourse do not strike me as being conducive to the emergence of genuine dialogue for several reasons. First, moral dialogue clearly compels me to view that Other as an end, not as a means. Second, by sticking to a precise, predetermined answer, I rule out ahead of time any unexpected contribution, which would be looked upon as a "deviation." Such impermeability to the influence of the Other runs counter to the very spirit of dialogue, which by definition seeks to transcend a one-sided flow of ideas. Third, by deciding beforehand upon the ends to be reached, I eliminate the possibility that we might together work out an answer to a moral problem. The right answer simply recapitulates the positions held by authority and the dialogue ends up being a pretence at joint exploration. As Nel Noddings writes: "True dialogue is open; that is, conclusions are not beld by one or more of the parties at the outset. The search for enlightenment, or responsible choice, or perspective, or means to problem solution is mutual and marked by appropriate signs of reciprocity." 24

The elenchus centered on instruction, as in the Meno, does not combine well with the required openness of moral dialogue. But the elenchus is not only 
a method of instruction. When theories relating to moral education refer to the Socratic "method" or "pedagogy," it is mostly to apprehend it as a process generating dissatisfaction about beliefs or assumptions. As an example, Kohlberg states that: "The first step in teaching virtue, then, is the Socratic step of creating dissatisfaction in students about their knowledge of the good."25

\section{The Morally Therapeutic Effect on the Elenchus}

Moral education researchers' interest in the "Socratic method" seems to focus around its destabilizing effect on claims to knowledge. Daniel Pekarsky criticizes this conception of the elenchus which he identifies with what is meant by the expression "Socratic teaching.", 26 What is at stake is the therapeutic or cathartic action of the elenchus induced by a state of perplexity accompanied by feelings of humility and by a liberation from false beliefs. It may seem farfetched to challenge the validity of inducing perplexity. Pekarsky is aware of that but wonders whether the high value given to perplexity in our society is not a manifestation of a nearly untouchable belief at the heart of Western civilization ever since Socrates. ${ }^{27}$

In order to be complete, the purge practised by Socrates requires that the opinion, inadequately judged as right, be led toward the fall into perplexity and confusion and then directed toward knowledge. Who, however, will be ready to let go and abandon long-held beliefs ? ${ }^{28}$ Pekarsky asks if Phaedo, Meno, or Glaucon would be ready to make the journey from perplexity to knowledge or would they end their lives in perplexity or new forms of prejudice? Such questions about the effects of Socratic therapy arise in situations where the elenchus undermines a core belief of someone who is not ready to give it up and who considers it to be linked to the foundation of his identity.

On this point, Pekarsky notes that unlike Socrates, who was eager to administer perplexity therapy to everyone, Dewey felt that perplexity becomes desirable only insofar as it may awaken the thinking process without also producing burdensome or demoralizing effects. Building upon this Dewyan position, Pekarsky argues that "given reasonable educational purposes it is, indeed, permissible for the teacher to bring the student into perplexity that he or she may be unable to overcome, but only if the teacher has good reason to think that the student is capable of tolerating this perplexity without adverse consequences for his or her emotional or intellectual growth." 29 This implies that the potential efficiency of Socratic teaching is relative to the teacher's ability to understand and take into account not only the belief system but also the character of the students. ${ }^{30}$ I would add that the capacity to tolerate the perplexity should also be linked to the level of trust prevailing in the classroom. The "therapy" of throwing beliefs off balance, when applied in a classroom devoid of any relationship of trust, may only serve to make some participants feel the anger of frustration in reaction to the doubt publicly cast on their personal beliefs. Or, it may only give rise to "academic doubt.",31

Another obstacle to the morally therapeutic effect of the destabilization of beliefs consists in the reductionist conception of the ethical Self on which the elenchus is based. In Socrates' (and Plato's) philosophy, this Self seems interconnected with the capacity to demonstrate, using argumentative answers, ${ }^{32}$ a proper knowledge about the nature of virtues: "if you cannot pass the stiff 
Socratic tests for knowledge you cannot be a good man." 33 So, when Socrates" interlocutor is unable to give a satisfying definition of a virtue, this not only represents an intellectual defeat but also a moral disaster. ${ }^{34}$ Failing the Socratic test, thus, carries the further consequence of sending the "guilty" interlocutor back to the "Know thyself" engraved on the Delphic temple. This motto, which inspired Socratic thought, entrusts the Self with the task of reaching its private moral truth alone.

The key to seeing whether the search for this personal truth is well on its way resides in the use of language indicating consistency and noncontradiction. But these criteria constitute major characteristics of what Jerome Bruner calls a logico-scientific (or paradigmatic) mode of thinking. ${ }^{35}$ Bruner contrasts this logico-scientific mode of thinking with the narrative mode of thinking. Recalling a distinction initially made by Richard Rorty to differentiate certain types of philosophies, Bruner gives us to understand that the epistemological question of "how to know truth" haunts the paradigmatic mode of thinking while the narrative mode is rather haunted by "how we come to endow experience with meaning." 36 It is obvious that the existence of the narrative mode is quite ancient, but "acknowledging" its importance for the development of the person and the study of its characteristics through the social science is of more recent origin. This "narrative turn," as Bruner calls it," has triggered a reconceptualization of the Self, the identity of which is now perceived as a "distributed" construction rather than being strictly personal. ${ }^{38}$ The Self as defined by the narrative mode of knowledge challenges two fundamental assumptions about the ethical Self in Plato's philosophy: 1) the development of the ethical Self relies essentially on itself; and 2) this development is based on the paradigmatic or logico-scientific mode of thinking centered on argumentation.

The stand taken by Platonic philosophy on self-construction of the moral Self and on the favoured use of the paradigmatic mode of thinking to develop the Self has served as a pillar for Western secular moral education. In the past few years, other ways of conceiving the ethical Self and the modes of thinking present in the learning of moral dialogue have been expressed. In this line of thought, we must emphasize the works of Nel Noddings and Carol Witherell who apprehend the ethical Self as a relational entity and the moral dialogue as an essential element in a relationship of solicitude allowing "the negotiations of meanings through which the self in relation to other selves and to one's cultural communities is constituted." 39

\section{Type of Rationality}

In this section, I will take a closer look at the type of rationality behind the elenchus which was already addressed indirectly when I talked about the ethical Self. Martha Nussbaum presents a particularly interesting reflection on the subject $^{40}$ based on a comparison between the elenchus in Greek tragedies and the Platonic elenchus. In Plato's time, tragedies represented a major source of ethical teaching. Too often, according to Nussbaum, our contemporary way of looking at Plato leads us to ask why his dialogues are not formulated as philosophic treatises rather than why they do not constitute poetic dramas like those of Sophocles or Aeschylus. ${ }^{41}$

In both the tragic and the Platonic elenchus, we find a descent into 
perplexity ${ }^{42}$ : "we begin with the confident assertion of a general position, made by a character over-optimistic about his grasp of and control over practical problems." 43 This state of hubris involving a claim to knowledge is then shattered and, consequently, the character plunges into perplexity. However, the similarities end here since the Platonic elenchus also presents itself as the antithesis of the tragic one. This antithetical character of the Platonic elenchus manifests itself by resorting in the dialogues to a familiar level of language rather than to a poetic one. According to Nussbaum, this choice can be explained by a will to avoid arousing emotions associated with poetic discourse. ${ }^{44}$ In Republic X, Plato states that poetry "waters" our emotions, whereas what a text should do above all is to dry them up. ${ }^{45}$ This strong distrust of emotions and the poetic tragedy that nurtures them incites Plato to bring Socrates' interlocutors to experience an elenchus completely distinct from the one experienced by the heroes in the tragedies:

The elenchus of tragedy works above all through the emotions and the sensuous imagination. Creon learns not by being defeated in an argument, but by feeling the loss of a son and remembering a love that he had not seen or felt truly during the loved one's life. . . . The tragedy even suggests that Creon's feelings were, all along, more deeply rational than his intellect ... . The Platonic elenchos is deeply suspicious of this. It teaches by appeal to intellect alone; learning takes place when the interlocutor is enmeshed in logical contradiction. ${ }^{46}$

Platonic dialogue, thus, shows a rupture with tragedy. ${ }^{47}$ This rupture is mostly marked by a transformation in the type of rationality of the elenchus, which becomes, with Plato, strictly intellectual. Another difference between the two types of elenchus consists in the contrasting value each of them gives to the general and to the particular. In Platonic cross-examination, "without a grasp of the general form, particulars cannot be objects of insight.",48 The tragic elenchus, on the other hand, tries to make us feel the irreducibility of the particular: ". . . the force of tragedy is usually, too, to warn us of the dangers inherent in all searches for a single form: it continually displays to us the irreducible richness of human value, the complexity and indeterminacy of the lived practical situation." 49

By basing the dialogical elenchus on an exclusively intellectual rationality oriented towards the general, one wonders if Plato is not laying down a foundation which is unfavourable to moral learning. Is educating people in controlling their emotions not as dangerous as encouraging them to continually express them freely? And, would not the constant abstraction of the particular at the expense of the general risk neutralizing what nurtures the complexity of a situation-namely, the links between the people concerned and the specific circumstances related to the problem?

Theoreticians of the ethics of care such as Carol Gilligan and Nel Noddings strongly argue that moral reasoning requires an understanding of the particularities of the Other and of the context of a given situation. What this type of reasoning requires is summarized by Lawrence Blum:

an intertwining of emotion, cognition, and action not readily separable. Knowing what to do involves knowing others and being connected in ways involving both emotion and cognition. ${ }^{50}$ 
While developing this theoretical framework, Nel Noddings has been especially interested in describing a specific type of reasoning, "interpersonal reasoning" as she calls it, which is used regularly in moral dialogue related to solicitude:

In contrast to logico-mathematical reasoning that proceeds step by step according to a priori rules, interpersonal reasoning is open, flexible, and responsive. It is guided by an attitude that values the relationship of the reasoners over any particular outcome, and it is marked by attachment and connection rather than separation and abstraction..$^{51}$

Thus, one of the characteristics of interpersonal reasoning is to favour the relationship between the reasoners rather than attaining a specific result. This last statement serves as an introduction to our last section which concerns caring for others.

\section{Caring for Others}

Scholars indirectly address Socrates' practice of caring when they question his use of the eristic form in dialogue. Eristic is generally defined as the art of defeating an adversary and is often associated with a form of argumentation practised by the Sophists. ${ }^{52}$ According to Janice Moulton, the elenchus is never a warlike practice employed by Socrates in order to "settle a score" with his adversaries. In her opinion,

There seems to be no reason to doubt that Socrates' praises were sincere and his jokes and sarcasm were nothing more than banter. The refusals and angry responses Socrates received were often in spite of his humour and praise, a result of resistance to having cherished ideas shaken and not a result of any adversary treatment by Socrates. . $^{33}$

Socrates has also been described by Matthew Lipman as a researcher having a passion for wisdom, not for victories: "What Socrates stresses is the continued prosecution of philosophical inquiry by following the reasoning wherever it leads (confident that, wherever it leads, wisdom lies in that direction), not the heavy breathing and clanging of armor in dialectical battles, where the premium is not on insight but on victory.",54

Moulton and Lipman perceive Socrates as not having adversarial strategies towards his interlocutors. On the other hand, Robert Beck considers that the type of interlocutor the philosopher is addressing sometimes determines a correspondence between the elenchus and eristic tactics. In his view, the strong competitive atmosphere prevailing at that period among the Greek educators forced Plato (and Socrates) to resort to eristic tactics in the dialogues with his rivals-namely, the Sophists. ${ }^{55}$ However, he also maintains that in other dialogues what we are witnessing is more of a relationship between teacher and student than between rivals and, in the latter case (for example, in the Theaetetus), the elenchus plays a cathartic role rather than an eristic one. ${ }^{56}$

Even if we accept the hypothesis of a cathartic elenchus used with adolescents and men "open" to Socrates' teachings, and of an eristic elenchus used with rivals, we have seen that the "purge of beliefs" raises many ethical problems.

Thus, when Socrates questions his companions, their replies usually amount to a simple affirmation: "Indeed, Socrates; yes, that is plain; of course, 
Socrates."57 From the standpoint of developing an argument, these replies confirm the building of a consensus but they also point to a lack of any real dialogue among the seekers of truth. The creativity in working out solutions and the development of the argument's logic both essentially remain one-sided.

Another ethical problem is raised by what the elenchus essentially aims to do-that is, destabilize beliefs. The problem arises when such destabilization is used systematically with no allowance for the demobilizing effect that this cognitive disequilibrium may cause to some people or group of people. Destabilization is still routinely perceived today as a "royal path" to educate. Belenky et al. have advanced the idea that this teaching approach may not constitute the best pedagogical strategy to use when teaching women. They maintain that women's tendency to doubt about themselves incline them to experience the brutal challenging of their ideas as debilitating rather than energizing: " $\mathrm{Be}$ cause so many women are already consumed with self-doubt, doubts imposed from the outside seem at best redundant and at worst destructive, confirming the women's own sense of themselves as inadequate knowers." 58 Although they acknowledge that cognitive conflict may be conducive to development, they hold that women, in particular, stand to gain from teaching that seeks to encourage them to have confidence in their ideas rather than doubt.

Finally, it is worth remembering that the strict intellectual rationality upon which the elenchus rests and its orientation towards the general may produce people who are highly skilful at debating their beliefs but unwilling to be moved by emotions and unprepared to negotiate their way through the complexity of real-life situations.

As regards the ethical problem of the relationship to the Other, I believe, as does the philosopher Gregory Vlastos, that Socrates did care for others but that his caring was limited and conditional.

I will put all my cards on the table and say that behind this lay a failure of love. In saying this, I am not taking over-seriously the prickly exterior and the pugilist's postures. I have already argued that [Socrates] does care for the souls of his fellows. But the care is limited and conditional. If men's souls are to be saved, they must be saved his way. And when he sees they cannot, he watches them go down the road to perdition with regret but without anguish. Jesus wept for Jerusalem. Socrates warns Athens, scolds, exhorts it, condemns it. But he has no tears for it. ${ }^{59}$

Vlastos diagnoses a "lack of love" in Socrates that kept him from really caring about other people's difficulties (souls must be saved his way). Does love really constitute a prerequisite for caring for others? In the ethics of caring described by Nel Noddings, caring for others is linked to the presence of an "encounter" with the Other (to define the "encounter," Noddings takes up the "I-Thou" concept developed by Martin Buber) rather than the presence of a prior feeling of love towards him or her. This "encounter" can, indeed, take place in a context where the interlocutors even feel hostility towards each other. In such a case, the "encounter" happens unexpectedly and involuntarily, as when the Other suddenly appears to me in a new light in his or her particular richness. Buber describes this new relationship this way: "He is no longer $\mathrm{He}$ or She, limited by other He's and She's, a dot in the world grid of space and time, nor a condition that can be experienced and described, a loose bundle of named qualities. Neighborless and seamless, he is Thou and fills the firmament." 60 
Receptivity rather than love can be found at the heart of such an "encounter," and, in the ethics of solicitude elaborated by Noddings, "encounter" and "receptivity" are intrinsically linked to moral dialogue. 61

It appears that, for Socrates, the Other rarely represents an irreplaceable and irreducible "Thou." In other words, the philosopher seems more concerned about a "deep intellectual cleansing" of every soul met on his path than with meeting Other qua Other. David Hansen's analysis of the Theaetetus confirms this hypothesis. In fact, Hansen maintains that in this dialogue, Socrates acknowledges being himself a victim of a sickness that pushes him to confront every person coming close to him: "For him, it seems to be "heaven's will" that he pursue the truth when the opportunity arises-regardless of who the other interlocutors are .... But whose will is it that he "wrestle" in debate with all who draw too near?" 62

It is important to underline that this strong tendency to "generalize" 63 the Other does not exclude the idea that Socrates is concerned about adapting his interventions to his interlocutors. I can very well intend to "test" the knowledge of many people by using, for each person, a language appropriate to his or her "persona." Nonetheless, this remains quite different from being touched or-using Noddings' terms-“being engrossed" by the Other. And as long as my sole test project "fills the firmament," the Other remains a means to fulfill my mission.

To summarize, we would say that in the elenchus directed by Socrates, the Other is regularly apprehended as "any other" the philosopher could "sting", (the like gadfly ${ }^{64}$ ) to provoke an examination of his profound beliefs.

\section{Conclusion}

For a long time in moral education, the "Socratic method" has represented a paragon of moral dialogue. This model, however, carries certain ethical assumptions that are debatable. In fact, it appears essential to cast a critical look on the following characteristics that may accompany Socraticallyinspired moral education: moral reasoning based on a logico-scientific rationality, ambiguous openness of the dialogue, intellectual construction of the ethical Self, unconditional adherence to the destabilization of beliefs, and focus put on the "Generalized Other."

I would like to thank Lucille Roy Bureau, Nel Noddings, and Lucien Morin for their thoughtful reading and comments on this manuscript. I also wish to thank the anonymous reviewers who made many helpful suggestions. 


\section{Notes}

1 Although I confine myself in this article to Socrates' prestige in moral education, it seems that the tendency to look positively at Socrates is widespread in our time, something that was not the case in the last century. See Martha C. Nussbaum, "Aristophanes and Socrates on Learning Practical Wisdom" in Aristophanes: Essays in Interpretation, edited by Jeffrey Henderson (Cambridge: Cambridge University Press, 1980), 44.

2 See Matthew Lipman, Philosophy Goes to School (Philadelphia, PA: Temple University Press, 1988), 3; Lawrence Kohlberg, The Philosophy of Moral Development (San Francisco, CA: Harper and Row, 1981), 3; John Wilson and Barbara Cowell, Taking Education Seriously (London, ON: The Althouse Press, 1989), 91.

3 See Nel Noddings, Philosophy of Education (Boulder, CO: Westview Press, 1995), 8, and David A. Garvin, "Barriers and Gateways to Learning"' in Education for Judgement: The Artistry of Discussion Leadership, edited by C. Roland Christensen (Boston, MA: Harvard Business School Press, 1991), 11. For example, Nel Noddings considers that students about to become professional teachers should ask themselves whether Socrates demonstrated proper respect for his students' dignity if he occasionally imposed his views and if it is right to cross-examine a student relentlessly in front of his peers? On the other hand, David Garvin questions whether the Socratic method "in which conclusions are preordained and the instructor's goal is to lead students to a particular answer through an established line of reasoning" constitutes a real discussion since, according to Garvin, all discussion is inherently uncertain.

${ }^{4}$ I will not attempt to dissect the logical mechanism of the elenchus or argue its status as a "method"; these are two preoccupations that fall much more within the domain of epistemology than ethics.

5 Noddings, Philosophy of Education, op. cit., 6: " . . . most students of education . . . associate [the name of Socrates] with the 'Socratic method.' This method of teaching, ... begins with the teacher posing a deceptively simple question such as. ... What does it mean to be just? When a student answers, the teacher responds with another question that prompts him or her to think more deeply and offer a new answer. The process_also called destructive crossexamination elenchus ... ."; Daniel Pekarsky, "Socratic Teaching: A Critical Assessment," Journal of Moral Education, 23, 2 (1994): 132, note 4: "Socratic teaching, or, as it is technically called, elenchus . . ." ; Janice Moulton, "Dualism in Philosophy," Teaching Philosophy, 3, 4 (1980): 423: "The Socratic method is frequently identified with the elenchus, a method of discussion designed to lead the other person into admitting that her or his views were wrong, to get them to experience a certain feeling, usually translated as 'shame' and sometimes as "humility'."

${ }^{6}$ Lawrence Kohlberg, The Philosophy of Moral Development (San Francisco, CA: Harper and Row, 1981), 29.

7 Many experts in this domain put Plato's dialogues into two categories to differentiate between a period where Platonic thought seems more linked to Socrates and another where it becomes more distant from it. These two categories are "early" or "Socratic" dialogues (composed by c. $388 \mathrm{BC}$ ) and "later" dialogues (composed between 367 and $347 \mathrm{BC}$ ). See, for example, 
Sophie Haroutunian-Gordon, "Plato and Education" in International Encyclopedia of Education, 8, edited by Husen Torsten and T. Neville Postlethwaite, 2nd edition (Oxford: Pergamon Press, 1994), 4532.

${ }^{8}$ Kohlberg was not only inspired by the "Socratic" or "early dialogues" when establishing the bases of certain aspects of his discussion theory, but he also considered Socrates as a paradigm of his highest level of moral development. Martha Nussbaum points out that if one adheres to the logic of this theory, criticizing Socrates then reveals that we are "stuck" at a lower level of development (see Nussbaum, "Aristophanes and Socrates on Learning Practical Wisdom," op. cit., 45).

9 The elenchus is sometimes referred to as elenchos. (See, Martha C. Nussbaum, The Fragility of Goodness. Luck and Ethics in Greek Tragedy and Philosophy (New York: Cambridge University Press, 1986), 129.

10 See G.B. Kerferd, "Le sophiste vu par Platon: Un philosophe imparfait" in Positions de la sophistique, edited by Barbara Cassin (Paris: Librairiephilosophique J. Vrin, 1986), 24

11 See Richard Robinson, "Elenchus", in The Philosophy of Socrates, edited by Gregory Vlastos (New York: Doubleday and Company Inc., 1971), 79.

12 Gregory Vlastos, "The Socratic Elenchus," Oxford Studies in Ancient Philosophy, 1 (1983): 27-28: “So the 'What is F?' question which Socrates pursues elenctically about other things, he never poses about the elenchus, leaving us only his practice of it as our guide when we try to answer it ourselves."

13 Robinson, "Elenchus," 78.

14 Ibid.

15 Plato, Sophistes, 230 c-d.

16 See Robert H. Beck, "Plato's Views on Teaching," Educational Theory, 35, 2 (1985): 121.

17 Ibid.

18 Gregory Vlastos, "The Paradox of Socrates" in The Philosophy of Socrates, edited by Gregory Vlastos (New York: Doubleday and Company Inc., 1971), 7-8.

19 Ibid., 11.

20 Beck, op. cit., 120. Beck even describes the slave as "a mere ventriloquist's dummy.",

21 I am using Viviane Robinson's expression to refer to the approach to dialogue used in Nicholas C. Burbules, Dialogue in Teaching: Theory and Practice (New York: Teachers College Press, 1993). See, also, her "Dialogue Needs a Point and Purpose,"' Educational Theory, 45, 2(1995): 243.

22 Burbules, op. cit., 121.

23 Beck, op. cit., 119: "Plato's opinion about the ideal for of teaching for those who have left childhood behind has been isolated in the phrase 'the Socratic method.' The Meno is cited as offering sufficient example and explanation."

24 Nel Noddings, "An Ethic of Caring and Its Implications for Instructional Arrangements," American Journal of Education, 45, 2(1988): 223.

25 Kohlberg, op. cit., 47.

26 Pekarsky, op. cit., 119-134.

27 Ibid., 122. 
28 Martha Nussbaum also emphasizes the fact that this problem has been neglected in the "early" dialogues. See Nussbaum, "Aristophanes and Socrates on Learning Practical Wisdom," op. cit., 86.

29 Pekarsky, op. cit., 126.

30 Ibid., 132.

31 This notion is borrowed from C.S. Pierce and quoted in Pekarsky, ibid., 127. Pierce opposes the "merely academic doubt" to the "real and living doubt." "Merely academic doubt" grows from an awareness that one's belief is questionable, or at odds with other beliefs one holds; what makes it "merely academic doubt" is that the agent is untroubled by it and is not moved by it to serious inquiry.

32 We must also remember that for Socrates, and contrary to the Sophists, this argumentation must be accompanied by personal adherence to the thesis one is arguing.

33 Vlastos, op. cit., 6 .

34 Ibid.

35 J. Bruner, Actual Minds, Possible Worlds (Cambridge, MA: Harvard University Press, 1986), 13.

36 Ibid., 12.

$37 \mathrm{~J}$. Bruner, Acts of Meaning (Cambridge, MA: Harvard University Press, 1990), 114.

${ }^{38}$ Ibid., 113-114.

39 Nel Noddings and Carol Witherell, "An Invitation to Our Readers" in Stories Lives Tell: Narrative and Dialogue in Education, edited by Nel Noddings and Carol Witherell (New York: Teachers College Press, 1991), 7.

40 Martha C. Nussbaum, The Fragility of Goodness (New York: Cambridge University Press, 1986), 122-135.

41 Ibid., 122.

42 Pekarsky (op. cit., 122) also mentions this symmetry with tragedy.

43 Nussbaum, The Fragility of Goodness, op. cit., 128.

44 According to Gallo, the Platonic position of distrust towards emotions can also be understood ". . . as the legacy of the shift from matrilineal to patrilineal socio-political structures and religious beliefs, and of the consequent devaluation of attributes connected to female entities." See Delores Gallo, "Educating for Empathy, Reason, and Imagination"' in Re-thinking Reason: New Perspectives in Critical Thinking, edited by Kerry S. Walters (Albany, NY: State University of New York Press, 1994), 48. Nevertheless, Plato did not adhere to that position all of his life. As Nussbaum writes: " . . the Phaedrus displays a new view of the role of feeling, emotion and the particular love in the good life"' (The Fragility of Goodness, op. cit., 133).

45 Plato, Republic, 606d, cited in Nussbaum, ibid., 133.

${ }^{46}$ Nussbaum, ibid.

47 However, the style of writing used by Plato shows a certain continuity with drama. Nussbaum (ibid., 134) affirms that: "By writing philosophy as drama, Plato calls on every reader to engage actively in the search for truth. By writing it as an anti-tragic drama, he warns the reader that only certain elements of them are appropriate to this search."

48 Ibid., 134. 
49 Ibid.

50 Lawrence A. Blum, "Gilligan and Kohlberg: Implications for Moral Theory" in An Ethic of Care, edited by Mary Jeanne Larrabee (New York: Routledge, 1993), 52.

51 Nel Noddings, "'Stories in Dialogue: Caring and Interpersonal Reasoning" in Noddings and Witherell, op. cit., 158.

52 See, for example, Lipman, op. cit., 14. However, eristic is not a method of argumentation exclusive to the Sophists: " . . . to be an eristic, it is not necessary to belong to a determined group and it is not required either to use a very precise method of argumentation. Anyone can become an eristic. He or she only has to try to win in a debate without being preoccupied by the truth." (My translation. Kerferd, op. cit., 14.)

53 Moulton, op. cit., 425-426.

54 Lipman, op. cit., 14.

55 See Beck, op. cit., 120-121.

56 For a critic of Socrates' presumed role of teacher in the Theaetetus, see David T. Hansen, "Was Socrates a 'Socratic Teacher'?", Educational Theory 38, 2 (1988): 213-224.

57 See M. Walzer, (1990), "A Critique of Philosophical Conversation" in Hermeneutics and Critical Theory, edited by H. Kelly (Cambridge: MIT Press, 1990), 182-196.

${ }^{58}$ M. Belenky, B. Clinchy, N. Goldberger, \& J. Tarule, Women's Ways of Knowing: The Development of Self, Mind, and Voice (New York: Basic Books, 1986), 228.

59 Vlastos, op. cit., 16.

60 Martin Buber quoted by Nel Noddings, Caring: A Feminine Approach to Ethics and Moral Education (Berkeley, CA: University of California Press, 1984), 74.

61 See Nel Noddings, "Learning to Engage in Moral Dialogue," Holistic Education Review, 7, 2 (1994): 5-11.

62 Hansen, op. cit., 224.

63 See Seyla Benhabib, "The Generalized and the Concrete Other: The Kohlberg-Gilligan Controversy and Moral Theory" in Women and Moral Theory, edited by Eva Feder Kittay and Diana T. Meyers (Totowa, NJ: Rowman and Littlefield, 1987), 154-177.

64 In Plato, Apology, 30e, Socrates actually declares that he is to the Athenian people as a gadfly to a noble but sliggish horse. 